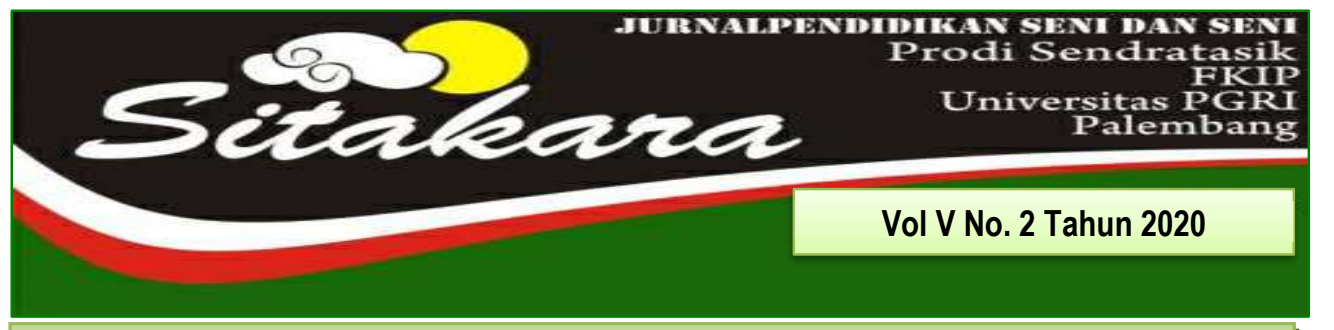

FUNGSI DAN MAKNA BHAJAN PADA UPACARA AGAMA HINDU DI KUIL SHRI MARIAMMAN KOTA MEDAN

(Agung Suharyanto, dkk)

KESENIAN SRANDUL DALAM UPACARA BERSIH DESA BULU KALURAHAN KARANGMOJO KECAMATAN KARANGMOJO KABUPATEN GUNUNGKIDUL YOGYAKARTA

(Supriyanto)

FUNGSI DAN MAKNA LAGU GUBANG DALAM UPACARA SIAR MAMBANG PADA MASYARAKAT TANJUNGBALAI

(Theo henry tua siagian ${ }^{1}$, pulumun p. Ginting ${ }^{2} \&$ wiflihani)

FUNGSI TARI MAPAK ADAT MUARA KUANG SEBAGAI TARI SAMBUT

(Nadia Rahma Aprilia', Dessy Wardiah², Treny Hera ${ }^{3}$ )

MAKNA SIMBOLIK RAGAM HIAS PADA RUMAH LIMAS PALEMBANG

(Ferri Hidayad ${ }^{1}$ Decky Kunian ${ }^{2}$ )

GAYA MUSIK SAHILIN DALAM KESENIAN MUSIK BATANGHARI SEMBILAN DI KOTA PALEMBANG

(Feri Firmansyah)

TRANSPOSISI TTI (TRANSFER, TRANSLATION, IMITATE) DALAM PEMBELAJARAN NOTASI MUSIK MELALUI SCORE CREATOR

(A Heryanto ${ }^{1}$ Dedy Firmansyah ${ }^{2}$ )

RASE TAK SERUPE MUSIK MELAYU TRADISI DENGAN PENGEMBANGAN MUSIK MODERN DALAM RUANG PERTUNJUKAN KOMPOSISI MUSIK NUSANTARA (Rio Eka Putra)

BENTUK SYAIR LAGU DALAM PERTUNJUKAN SYAROFAL ANAM DI PEDESTRIAN S UDIRMAN KOTA PALEMBANG

(Nofroza Yelli ${ }^{1}$ Deria Sepdwiko² ${ }^{2}$

"Betenun" Sebuah Wujud Proses Kreatif Mahasiswa Seni Pertunjukan Universitas PGRI PALEMBANG

(Nurdin $^{1}$ Naomi Diah Budi Setyaningrum ${ }^{2}$ ) 
DAFTAR ISI

FUNGSI DAN MAKNA BHAJAN PADA UPACARA AGAMA HINDU DI KUIL 1-15 SHRI MARIAMMAN KOTA MEDAN

(Agung Suharyanto, dkk)

KESENIAN SRANDUL DALAM UPACARA BERSIH DESA BULU KALURAHAN

$16-26$

KARANGMOJO KECAMATAN KARANGMOJO KABUPATEN GUNUNGKIDUL YOGYAKARTA

(Supriyanto)

FUNGSI DAN MAKNA LAGU GUBANG DALAM UPACARA SIAR MAMBANG 27-39 PADA MASYARAKAT TANJUNGBALAI

(Theo henry tua siagian ${ }^{1}$, pulumun $p$. Ginting ${ }^{2} \&$ wiflihani)

FUNGSI TARI MAPAK ADAT MUARA KUANG SEBAGAI TARI SAMBUT

40-52

(Nadia Rahma Aprilia', Dessy Wardiah², Treny Hera')

MAKNA SIMBOLIK RAGAM HIAS PADA RUMAH LIMAS PALEMBANG

53-61

(Ferri Hidayad ${ }^{1}$ Decky Kunian ${ }^{2}$ )

GAYA MUSIK SAHILIN DALAM KESENIAN MUSIK BATANGHARI SEMBILAN DI $\quad 62-76$ KOTA PALEMBANG

(Feri Firmansyah)

TRANSPOSISI TTI (TRANSFER, TRANSLATION, IMITATE) DALAM 77-85 PEMBELAJARAN NOTASI MUSIK MELALUI SCORE CREATOR (A Heryanto ${ }^{1}$ Dedy Firmansyah ${ }^{2}$ )

RASE TAK SERUPE MUSIK MELAYU TRADISI DENGAN PENGEMBANGAN MUSIK MODERN DALAM RUANG PERTUNJUKAN KOMPOSISI MUSIK NUSANTARA

(Rio Eka Putra)

BENTUK SYAIR LAGU DALAM PERTUNJUKAN SYAROFAL ANAM DI PEDESTRIAN SUDIRMAN KOTA PALEMBANG

(Nofroza Yelli ${ }^{1}$ Deria Sepdwiko ${ }^{2}$ )

"BETENUN" SEBUAH WUJUD PROSES KREATIF MAHASISWA SENI

$109-120$ PERTUNJUKAN UNIVERSITAS PGRI PALEMBANG

(Nurdin ${ }^{1}$ Naomi Diah Budi Setyaningrum ${ }^{2}$ )

86-95 


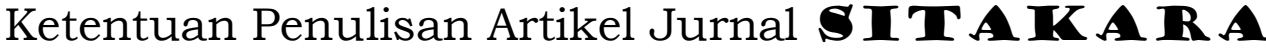

1. Naskah berbahasa Indonesia bertemakan Seni Budaya yang meliputi hasil penelitian pengajaran seni budaya, cabang seni, dan kebudayaan.

2. Naskah harus asli dan belum pernah dimuat dalam media lain. Naskah dapat berupa hasil penelitian perorangan atau kelompok.

3. Naskah ditulis dengan cara-cara yang sesuai dengan ketentuan penulisan artikel ilmiah menggunakan bahasa Indonesia yang baku, berupa ketikan, beserta soft line dalam CD-RW atau dengan mengirimkan email pada redaksi Jurnal SITAKA RA dengan alamat email: jurnalsitakarasendratasik@yahoo.com, spasi 1,5 jenis huruf Arrial Narrow ukuran 12, dengan panjang naskah antara 8-15 halaman pada kertas A4.

4. Artikel hasil penelitian memuat:

JUDUL

Nama Penulis

Abstrak

A. PENDAhuluan

B. METODE PENELITIAN

C. HASIL DAN PEMBAHASAN

D. SIMPULAN

5. Artikel kajian konseptual memuat:

JUDUL

Nama Penulis

Abstrak

PENDAHULUAN
: XXX (HURUF KAPITAL)

: (disertai jabatan dan institusi)

: (Bahasa Indonesia yang memuat 100150 kata diikuti kata kunci, dengan jenis huruf Arrial Narrow dan ukuran huruf 11 spasi tunggal serta dicetak miring)

: (Memuat latar belakang masalah, tinjauan pustaka secara ringkas, masalah penelitian dan tujuan penelitian)

: (Berisi simpulan)

\section{: XXX (HURUF KAPITAL)}

: (disertai jabatan dan institusi)

: (Bahasa Indonesia yang memuat 100150 kata diikuti kata kunci, dengan jenis huruf Arrial Narrow dan ukuran huruf 11 serta dicetak miring)

: (Memuat latar belakang masalah, tinjauan pustaka secara ringkas, 
Sub Judul

Sub Judul

SIMPULAN

DAFTAR PUSTAKA masalah penelitian dan tujuan

penelitian)

: Sesuai dengan kebutuhan (tanpa

numbering)

: (Berisi simpulan dan saran)

: (Berisi pustaka yang dirujuk dalam uraian naskah

6. Referensi sumber dalam teks artikel ditulis dengan menggunakan side note, contoh: (Jalalluddin, 1991:79); (Taufik, 2005;350); (Hamid dan Madjid, 2011:43). Sementara penulisan daftar pustaka disusun dengan ketentuan. Nama Pengarang. Tahun Terbit. Judul (dicetak miring). Kota Terbit: Nama Penerbit. Contoh: Koentjaraningrat. 2010. Manusia dan Kebudayaan Di Indonesia. Jakarta: Djambatan.

Daftar pustaka hanya memuat pustaka/sumber yang dirujuk dalam uraian dan disusun menurut abjad, tanpa nomor urut.

7. Naskah yang dimuat akan disunting kembali oleh redaksi tanpa mengubah isinya.

8. Naskah yang ditolak (tidak bisa dimuat) akan dikirim kembali ke penulis dengan pemberitahuan tertulis dari redaksi atau alamat email.

9. Penulis yang naskahnya dimuat akan mendapatkan 1 (satu) majalah nomor yang bersangkutan.

10. Contact Person: Treny Hera (085357344704) dan Mainur (081373165553). 


\title{
KESENIAN SRANDUL DALAM UPACARA BERSIH DESA BULU KALURAHAN KARANGMOJO KECAMATAN KARANGMOJO KABUPATEN GUNUNGKIDUL YOGYAKARTA
}

\author{
Oleh: \\ Supriyanto \\ (Fakultas Seni Pertunjukan Institut Seni Indonesia Surakarta) \\ Email: supriyantoisisolo@gmail.com
}

\begin{abstract}
ABSTRAK
Kesenian Srandul merupakan kesenian rakyat yang tumbuh dan berkembang di Yogyakarta dan Jawa Tengah. Kesenian ini sampai sekarang masih sering dipentaskan, baik sebagai upacara bersih desa maupun sebagai tontonan sekuler. Kesenian Srandul di desa Bulu, Karangmojo, Gunungkidu Yogyakarta, dipentaskan satu tahun sekali dalam rangkaian upacara bersih desa. Masyarakat dusun Bulu masih percaya tentang mitos bahwa wilayahnya dijaga oleh cikal bakal dusun Bulu yaitu Kyai Mojo. Srandul merupakan tari kelompok yang lebih sebagai dramatari, dimana dalam penyajiannya terdapat tarian, dialog, dan nyanyian yang diiringi dengan musik terbang, angklung, dan kecrek. Upacara bersih desa ini dilakukan dengan tiga tahapan yaitu persiapan, pelaksanaan, dan penutupan. Penelitian ini bersifat kualitatif, metode yang digunakan deskriptif analitis dengan pendekatan etnokoreologi. Pendekatan ini memandang tari sebagai produk budaya non barat, maka di dalam pendekatan ini, presentasi data dipaparkan secara visual fotografi.
\end{abstract}

Kata Kuci : Kesenian Srandul, Upacara Bersih Desa.

\section{A. PENDAHULUAN}

Bulu adalah nama sebuah dusun di desa Karangmojo yang terletak di sebelah timur Yogyakarta, kira-kira $30 \mathrm{~km}$ ke arah tenggara dari kota Yogyakarta. Di dusun Bulu Karangmojo ini terdapat kesenian Srandul yang khas, yang tidak dimiliki oleh daerah lain. Kesenian Srandul di dusun Bulu dimainkan dan digemari oleh warga masyarakatnya. Kesenian Srandul yang khas ini merupakan jenis kesenian rakyat yang sudah berpuluh-puluh tahun dikenal dan hidup di tengah-tengah masyarakat dusun Bulu. Fungsi utama kesenian ini sebagai pelengkap upacara bersih desa di dusun Bulu dan untuk hiburan bagi warga masyarakatnya. Dalam pertunjukan kesenian Srandul terkandung ajaran- ajaran moral, norma-norma sosial, dan pendidikan budi pekerti untuk pemeliharaan pergaulan sosial. Kesenian Srandul di dusun Bulu Karangmojo, Gunungkidul ini tampak dipengaruhi oleh ajaran-ajaran Hindu dan Islam. Hal ini dapat dikenali melalui unsur-unsur yang terkandung dalam serangkaian penampilannya; seperti pada dialog dan tembang yang dibawakan penari dan alat musik atau instrumen yang digunakan maupun upacara-upacara yang dilakukan. Upacara-upacara sesaji itu dilengkapi dengan bunga dan membakar kemenyan yang ditujukan untuk roh-roh, serta adanya hal mistis yang merupakan kepercayaan agama Hindu. Dengan adanya kepercayaan mistis itu akan membawa tuah bagi mereka.

Kesenian Srandul merupakan kesenian 
tradisional warisan nenek moyang secara turun temurun sebagai ekspresi masyarakat lingkungannya. Kesenian Srandul adalah kesenian rakyat yang berkembang di pedesaan. Masyarakat pedesaan masih memiliki rasa solidaritas yang tinggi dan kegotong-royongan yang kuat. Menurut Pigeaud, kesenian Srandul sudah ada sejak tahun 1930-an di daerah Kedu. Kesenian Srandul sampai di daerah Gunungkidul sekitar tahun 1940-an (Soedarsono, 1986:170). Kesenian Srandul merupakan peninggalan nenek moyang yang di dalamnya menceritakan kisah hidup sebuah keluarga dengan segala konfliknya yang menggunakan tari dan dialog tembang. Banyak yang menyebut kesenian Srandul sebagai teater daerah. Sumardjo (1987:18), menjelaskan bahwa "Seni teater adalah sesuatu yang sakral yang harus dilakukan secara sungguh- sungguh dengan segala hal seremonialnya. Pertunjukan teater tradisional tidak dapat sembarangan waktu diadakan, tetapi harus dipertunjukkan dengan suatu alasan dan maksud tertentu yang berhubungan dengan kepercayaan mereka. Walaupun demikian tidak berarti semua teater tradisional adalah sakral. Ada pula yang bersifat profan, manakala fungsi religinya telah dilupakan atau karena dasar religinya telah tidak sesuai lagi dengan religi baru, tetapi dasar estetikanya masih digemari." Menurut pendapat Jacob Sumardjo, seni teater yang tumbuh di tengah-tengah masyarakat tidak dapat dipisahkan dengan kehidupan masyarakat. Teater bukan sekedar tontonan tetapi merupakan bagian penting untuk memeriahkan upacara. Teater tradisional berkembang sesuai dengan perubahan masyarakatnya, atau dapat dikatakan teater rakyat mampu menyesuaikan diri dengan perkembangan masyarakatnya. Kesenian Srandul dalam objek penelitian ini dipentaskan rutin setahun sekali pada bulan Sapar dalam upacara bersih desa di dusun Bulu, kalurahan Karangmojo, kecamatan Karangmojo, kabupaten Gunungkidul Yogyakarta. Kesenian Srandul tersebut sebagai ucapan syukur masyarakat dusun Bulu yang telah diberikan tanah yang subur dan hasil pertanian yang melimpah. Masyarakat menganggap bahwa kesenian dan upacara merupakan bagian penting dalam kehidupannya.

Masyarakat mempercayai apabila di bulan Sapar tidak diadakan upacara bersih desa dan kesenian Srandul, maka akan terjadi bencana dan malapetaka yang menimpa dusun Bulu. Bentuk pertunjukan kesenian Srandul pada Upacara Bersih Desa bersifat sakral. Hal ini terbukti dengan adanya sesaji yang dapat mengundang roh-roh leluhur yang menjaga dusun Bulu, selain itu juga terdapat magi. Magi adalah sesuatu atau cara tertentu yang diyakini dapat menimbulkan kekuatan gaib, sehingga dapat menguasai alam sekitar termasuk alam pikiran dan tingkah laku manusia. Kesenian Srandul ini dipertunjukkan 
di halaman rumah atau tanah lapang yang dibuatkan panggung. Srandul ini ditarikan oleh satu penari putri dan sembilan penari laki-laki. Penari pada saat menari berdialog dengan menggunakan tembang dan pantun yang berisi tentang nasehat-nasehat kehidupan. Gerak pada kesenian Srandul masih sangat sederhana dan banyak menggunakan gerakgerak spontan. Ragam gerak tersebut antara lain ulap-ulap, sembahan, sirig, mabur, ukel tangan, seblak sampur, dan mubeng-mubeng. Posisi kaki untuk penari laki-laki umumnya terbuka, sedang untuk penari putri tertutup. Rias yang dipergunakan dalam Srandul ini realistis dan non realistis. Busana pada kesenian Srandul ini nampak realistis dan stilisasi, terdiri dari ikat kepala, baju surjan, kain atau selendang, sabuk, kamus timang. Pementasan dilakukan pada siang hari dari jam 10.00 sampai 16.00 sore.

Kesenian Srandul tidak hanya terdapat di Gunungkidul saja, tetapi juga terdapat di daerah lain, yang masing-masing memiliki ciri khas sendiri sesuai dengan daerah tempat kesenian Srandul hidup. Kesenian Srandul di dusun Bulu, kecamatan Karangmojo, Gunungkidul ini terdapat penyanggak yang tidak dimiliki oleh Srandul lain. Peranan penyanggak sangat penting, sebagai penutur ceritera semua peristiwa yang terjadi di atas pentas. Dengan kata lain penyanggak sebagai penyambung alur atau dhalang dengan menggunakan dialog dan tembang. Selain itu penyanggak dapat menentukan lama tidaknya adegan dalam suatu pertunjukan. Kesenian Srandul di dusun Bulu, Karangmojo Gunungkidul menarik untuk diteliti karena memiliki ciri khas adanya penyanggak sebagai penutur cerita atau dhalang. Selain itu kesenian Srandul ini dipentaskan secara rutin setiap bulan Sapar dalam upacara bersih desa di dusun Bulu Karangmojo, Gunungkidul.

\section{B. METODE PENELITIAN}

Penelitian ini bersifat kualitatif, data yang digunakan meliputi data lapangan dan data tertulis. Pendekatan yang digunakan adalah pendekatan etnokoreologi. Pendekatan ini memandang tari sebagai produk budaya etnik non barat, maka di dalam pendekatan ini presentasi data dipaparkan secara visual fotografi. Metode ini mencakup teknik-teknik penelitian dalam memecahkah masalah, dalam rangka pelaksanaan suatu proses penelitian digunakan metode deskriptif analitis, sehingga dapat memberikan gambaran, melukiskan, dan memaparkan data yang telah diperoleh tentang kesenian Srandul di dusun Bulu, kecamatan Karangmojo, kabupaten Gunungkidul Yogyakarta, untuk diklasifikasikan, dianalisis, dan diinterpretasikan secara lengkap.

\section{HASIL DAN PEMBAHASAN}

\section{Upacara Bersih Desa}

Upacara Bersih Desa adalah sebuah ritual yang harus dilaksanakan oleh masyarakat dusun Bulu, apabila tidak dilakukan mereka 
percaya akan terjadi bencana dan malapetaka yang menimpa dusun Bulu. Setiap Upacara Bersih Desa selalu ditampilkan kesenian Srandul sebagai pelengkap upacara. Terlaksananya Upacara Bersih Desa dan ditampilkannya kesenian Srandul tidak terlepas dari masyarakat yang masih mempercayai adanya mitos di dusun Bulu. Keterlibatan masyarakat ini dapat meningkatkan rasa solidaritas dan kegotongroyongan. Pada akhirnya kehadiran Upacara Bersih Desa dan kesenian Srandul menjadi bagian penting dalam sebuah keseimbangan hidup alam sekitar dan masyarakat di dusun Bulu. Soedarsono menyebutkan syarat terlaksananya upacara yaitu 1), tempat terpilih, 2). Pelaku terpilih, 3). waktu terpilih, 4). ada Pawang atau pemimpin spiritual, 5). Sesaji (Soedarsono, 1990:170). Teori ini dapat digunakan dalam menganalisis diadakannya upacara bersih desa di dusun Bulu, kecamatan Karangmojo, kabupaten Gunungkidul Yogyakarta. Masyarakat dusun Bulu percaya, apabila tidak diadakan upacara bersih desa akan terjadi bencana dan malapetaka yang menimpa dusun mereka. Upacara ini biasanya dihubungkan dengan peristiwa penting yang terjadi di masyarakat seperti gagal panen, kekeringan, wabah hama tanaman, dan lain-lain. Selain itu, juga menghasilkan peran ganda yaitu mempercayai roh-roh yang ditenangkan, dan solidaritas kerukunan masyarakat. Setiap satu tahun sekali pada bulan Sapar masyarakat dusun
Bulu kecamatan Karangmojo mengadakan Upacara Bersih Desa, sebagai ucapan syukur atas hasil panen pertanian yang didapat, di samping itu maksud dari upacara ini agar mereka terhindar dari malapetaka.

Upacara Bersih Desa ini diadakan di Sendang Mojo, tempat ini dipercaya masyarakat sebagai tempat keramat. Air di Sendang ini walaupun musim kemarau tidak pernah kering. Sampai saat ini Sendang Mojo merupakan sumber mata air utama dusun Bulu. Masyarakat wajib memelihara dan menjaganya. Selain itu masyarakat mempercayai mitos yang terdapat di sendang tersebut yang dapat untuk menyembuhkan orang sakit, cepat dapat jodoh, segera mendapat keturunan anak, kelancaran dalam hidupnya, dan sebagainya. Mitos merupakan cerita suatu bangsa, dewa dan pahlawan pada zaman dahulu, mengandung penafsiran asal usul alam semesta, manusia dan bangsa tersebut, dan mengandung arti mendalam yang diungkapkan dengan cara gaib.

\section{Pelaksanaan Upacara Bersih Desa}

Upacara Bersih Desa terbagi dalam beberapa bagian yaitu tahap persiapan, tahap pelaksanaan, dan tahap penutupan. Pada tahap persiapan warga masyarakat Bulu mengadakan rapat di rumah bapak kadus, membicarakan waktu pelaksanaan upacara, biaya yang dibutuhkan, komsumsi, dan lainlain. Dalam persiapan Upacara Bersih Desa ini dilakukan oleh semua kepala keluarga, warga 
dan sebagian ibu-ibu warga dusun Bulu. Sebelum Upacara Bersih Desa dilakukan, warga masyarakat mengadakan kerja bakti atau gotong royong untuk membersihkan Sendang, punden, dan tempat-tempat yang nanti akan dilalui dalam upacara. Sehari sebelum dilakukan Upacara Bersih Desa, warga masyarakat dusun Bulu mengadakan pengajian dengan membaca surat Yasin, dhikir dan tahlil, serta berdoa agar Upacara Bersih Desa dapat berjalan dengan lancar. Pengajian ini dihadiri oleh semua warga masyarakat dusun Bulu. Pengajian ini diadakan di masjid dusun Bulu dan dipimpin oleh modin sebagai kaum rois dusun Bulu.

Tahap pelaksanaan Upacara Bersih Desa, Masyarakat berkumpul di Sendang Mojo, untuk mengadakan slametan. Kegiatan ini dilakukan seluruh warga masyarakat dusun Bulu, hal ini dipercaya oleh warga dusun Bulu akan mendapatkan berkah. Clifford Geertz menjelaskan upacara Slametan melambangkan kesatuan mistis dan sosial, karena para handaitaulan, tetangga, rekan kerja, sanak keluarga, arwah setempat, nenek monyang, yang sudah meninggal dan para dewa, semuanya duduk bersamaan mengelilingi tempat yang untuk meletakkan makanan yang dipakai untuk slametan dan barang sesaji. Slametan ini diadakan tidak hanya dilakukan dengan maksud untuk memelihara solidaritas diantara para peserta upacara saja, melainkan dalam rangka memelihara hubungan dengan arwah nenek moyang mereka. Pada saat slametan ini warga masyarakat Bulu merasa adanya rasa kebersamaan, keakraban, duduk sama rata tampa memperhitungkan status sosialnya.

Siang harinya kira-kira pukul 11.00 mulai dipertunjukkan kesenian Srandul dalam Upacara Bersih desa yang disertai dengan sesaji. Dengan adanya sesaji dan membakar dupa maka pertunjukan itu terkesan mistis, hal ini sesuai dengan kepercayaan masyarakat dusun Bulu yang masih mempercayai adanya kekuatan-kekuatan gaib. IImu gaib itu dapat disebut sebagai emotionalist theories yang beranggapan bahwa perbuatan ilmu gaib itu bermaksud mencapai tujuan yang dirasakan oleh manusia terletak di dalam alam supernatural, karena hanya berusaha untuk menguasai dan mempergunakan kekuatan sakti (Koentjaraningrat,1958:197). Oleh sebab itu penampilan kesenian Srandul menjadi bagian akhir dari pelaksanaan Upacara Bersih Desa. Setelah upacara Bersih Desa dan pertunjukan kesenian Srandul selesai maka prosesi ditutup dengan pengajian di masjid dusun Bulu. Tahap penutupan ini dilakukan pada malam hari setelah pertunjukan Srandul selesai. Selain mengagungkan Asma Allah, warga masyarakat mengucapkan puji syukur atas pelaksanaan Upacara Bersih Desa yang telah berjalan dengan lancar dan selamat. Warga masyarakat juga berdoa memohon pada Tuhan Yang Maha Kuasa agar di dusun Bulu terhindar dari bencana dan malapetaka. Di samping itu juga memohon agar hasil 
pertaniannya terhindar dari wabah hama, sehingga hasil panennya baik serta seluruh usaha warga masyarakat Bulu dapat hasil yang melimpah. Mereka juga memohon agar dijauhkan dari pagebluk dan dijauhkan dari segala bencana alam. Secara keseluruhan masyarakat memohon agar perikehidupan dan penghidupannya menjadi tenteram, damai, dan aman. Sesepuh dusun menyatakan bahwa kesenian Srandul harus dipentaskan setiap bulan Sapar sebagai pelengkap Upacara Bersih Desa di dusun Bulu kecamatan Karangmojo. Menurut kepercayaan masyarakat dusun Bulu, Upacara Bersih Desa dan kesenian Srandul wajib dilaksanakan setiap tahun sekali pada bulan Sapar, apabila tidak dilakukan masyarakat menyakini akan terjadi bencana atau malapetaka (Wawancara dengan Tohari, 10 Oktober 2018). Hal ini pernah terjadi pada tahun 2003 pada bulan Sapar, karena adanya permasalahan yang terjadi di dusun Bulu dan tidak adanya dana, maka upacara bersih Desa dan pertunjukan Srandul tidak diadakan. Akibatnya air di sendang Mojo mengalami kekeringan dan gagal panen. Masyarakat dusun Bulu harus mencari air ke dusun lain untuk memenuhi kebutuhan seharihari. Setelah kejadian tersebut masyarakat dusun Bulu setiap setahun sekali pada bulan Sapar mengadakan Upacara Bersih desa dan pertunjukan kesenian Srandul.

Masyarakat dusun Bulu, Karangmojo sebagian besar memeluk agama Islam, dan sebagian kecil memeluk agama Kristiani. Dalam kehidupan mereka saling hidup berdampingan, saling tolong-menolong dan bergotongroyong. Masyarakat dusun Bulu Karangmojo dapat dikatakan masih lugu dan menerima warisan nenek moyang mereka secara turun temurun untuk melaksanakan Upacara Bersih Desa. Sebagai masyarakat agraris dalam kehidupannya, tidak akan terlepas dengan kesenian sebagai ekspresinya. Kesenian sebagai bagian hidup mereka digunakan sebagai hiburan dan sebagai pelengkap dalam upacara. Hal ini sesuai dengan kepercayaan masyarakat dusun Bulu yang masih mempercayai adanya mitos dan roh nenek moyang mereka. Koentjaraningrat menjelaskan bahwa dalam kehidupan manusia dalam suatau masyarakat menganut berbagai macam religi. Dalam kehidupan sehari hari kita banyak melihat, bahwa bentuk- bentuk kepercayaan itu merupakan unsur-unsur yang selalu bercampur dan terjalin erat dengan berbagai unsur keagamaan dalam masyarakat (Soedarsono, 1986: 269). Suatu religi dapat merupakan suatu kompleks yang terdiri dari unsur-unsur animisme, totemisme, mistik, dan sebagainya. Dengan demikian masyarakat dusun Bulu menganut nilai-nilai religi. Hal ini terbukti bahwa masyarakat Bulu sebagian menganut agama Islam tetapi masih percaya adanya mitos, dan roh -roh nenek moyang. Hubungan antara kesenian Srandul dalam Upacara Bersih Desa dan masyarakat dusun 
Bulu Karangmojo tidak saling mengganggu dan saling membantu serta saling membutuhkan. Hal ini terbukti dalam upacara tersebut dalam pembacaan doa secara Islam tetapi yang beragama Kristen juga mengikuti dengan kepercayaan mereka sendiri. Pelaksanaan upacara ini memiliki fungsi sosial yang sangat kental. Masyarakat Bulu merasakan kebersamaan saling membantu dan bergotong royong dalam melaksanakan Upacara Bersih Desa. Itulah nilai-nilai yang menonjol, di samping itu adanya kekuatan yang tak kasat mata. Masyarakat percaya adanya mitos tidak berani meninggalkan Upacara Bersih Desa dan pertunjukan kesenian Srandul. Masyarakat saling berinteraksi baik untuk melaksanakan upacara dan pertunjukan Kkesenian Srandul setahun sekali pada bulan Sapar. Mereka takut apabila tidak melaksanakannya, akan terjadi bencana atau malapetaka, seperti kekeringan, gagal panen, banyak hama, banyak terserang penyakit, dan lain-lain. Terhadap tempat-tempat sakral yaitu sendang Mojo dan Punden mereka selalu merawat keberadaannya sebab mereka percaya bahwa tempat tersebut sebagai tempat keramat dan memiliki kekuatan gaib. Sampai saat ini masyarakat dusun Bulu masih tetap melaksanakan Upacara Bersih Desa dan pertunjukan kesenian Srandul. Upacara dan kesenian Srandul telah menjadi tradisi di kalangan masyarakat Bulu. Masyarakat sebagai pendukung upacara tersebut tetap berupaya untuk melestarikan Upacara Bersih Desa dan pertunjukan kesenian Srandul. Oleh sebab itu ada beberapa alasan mengapa kesenian Srandul digunakan dalam Upacra Bersih Desa, yaitu:

1. Masyarakat mempunyai kepercayaan apabila tidak dilakukan Upacara Bersih Desa dan pertunjukan Srandul, akan terjadi bencana dan malapetaka yang menimpa mereka.

2. Masyarakat percaya adanya mitos bahwa dusun Bulu, dijaga oleh Kyai Mojo, dengan adanya Upacara Bersih Desa dan pertunjukan kesenian Srandul, sebagai wujud persembahan kepada roh leluhur.

3. Kesenian Srandul yang dipentaskan dalam Upacara Bersih desa tiap setahun sekali pada bulan Sapar sebagai wujud fungsi sosial.

4. Diadakan Upacara Bersih Desa dan pertunjukan Srandul agar air sendang Mojo tidak mengalami kekeringan.

5. Masyarakat percaya bahwa jika setiap tahun diadakan upacara Bersih Desa dan kesenian Srandul, dapat membawa berkah.

6. Makna dari cerita kesenian Srandul yang dibawakan merupakan petuahpetuah hidup.

\section{Bentuk Kesenian Srandul Dalam Upacara Bersih Desa}

Menurut Th Pigeaud dalam buku Javaanse Volksvertoningen pada tahun 1938, dalam 
buku ini membicarakan beberapa kesenian rakyat seperti lengger, Kudak kepang, Reog, Kethek Ogleng, Srandul, dan lain sebagainya. Menurut Pigeaud Srandul merupakan kesenian rakyat yang berada di daerah, Yogyakarta, dan Jawa Tengah. Pertunjukan Srandul di Kedu bersumber dari cerita Menak, yang inti ceritanya adalah gugurnya Wong Agung Jayengrana dalam perang melawan Raja Lakat, dan pembalasan Sayidina Ngali yang mengurung Raja Lakat. Anehnya, walaupun di dalam penjara tangan dan kakinya diikat, namun berhasil mendapatkan sepasang pakaian dan akhirnya dia dapat melepaskan diri (Pigeaud, 1938:461). Cerita ini menampilkan nilai-nilai dalam kehidupan masyarakat. Pertunjukan Srandul selalu mengembangkan cerita sesuai dengan kearifan lokalnya, sehingga pertunjukan ini berkembang terus dengan mengangkat cerita dari daerah masing-masing dimana kesenian Srandul itu hidup dan berkembang.

Kesenian Srandul tumbuh dan berkembang di berbagai daerah khususnya di Jawa Tengah dan Yogyakarta. Masingmasing daerah memiliki ciri khas sendiri, sesuai dengan kondisi masyarakat setempat. Kesenian Srandul dalam kehidupan masyarakat ada yang untuk pelengkap upacara, atau untuk tontonan dan hiburan. Kesenian Srandul dalam masyarakat memiliki bermacam-macam fungsi sesuai dengan kebutuhan masyarakat. Kesenian Srandul di dusun Bulu kecamatan Karangmojo,
Guniungkidul, berbentuk drama tradisional atau tetater tradisional. Bentuk pertunjukan disajikan dengan tingkah laku dan dialog. Dengan menyanyi dan menari yang diringi dengan tabuhan musik yang diselingi dengan lelucon.

\section{A. Cerita}

Kesenian Srandul di dusun Bulu Karangmojo, kabupaten Gunungkidul mempunyai sumber cerita sebagai berikut. Kerajaan Majapahit yang dipimpin oleh Raja Brawijaya bersedih hati karena putrinya Dewi Kenyowati hilang saat perjalanan di gunung Srandil. Raja Brawijaya memerintahkan para parajurit untuk mencarinya, akan tetapi tak seorangpun dapat menemukannya. Kemudian Brawijaya memerintahkan putra- putranya untuk mencarinya tetapi tidak dapat menemukan Dewi Kenyowati. Kemudian Sang Raja mengadakan sayembara Babad Alas Bromakoto di gunung Srandil, barang siapa yang dapat menemukan Dewi Kenyowati apabila laki-laki akan dijodohkan dengan Dewi Kenyowati dan apbila perempuan akan dijadikan saudara kandung Berita sayembara sampai di kraton Pajajaran Jenggala Manik, Raden Ganyong atau Ratu Anom bersama babdinya Klencer dan Memble berangkat mengikuti sayembara. Raden Ganyong bersama kedua abdinya membabat Alas Bromarkoto dan akhirnya dapat menemukan Dewi Kenyowati. Dewi Kenyowati akhirnya menjadi istri Raden Ganyong, tetapi ternyata Raden Ganyong telah mempunyai 
istri bernama Dewi Pembayun, tetapi Dewi Kenyowati tetap bersedia menjadi istri kedua. Ternyata Dewi Kenyowati seorang puti raja yang mempunyai sifat sangat jahat. Semua permintaan Dewi Kenyowati harus terpenuhi, termasuk minta perhiasan emas dan lumbung padi beserta seisinya. Raden Ganyong selalu memenuhi segala permintaan Dewi Kenyowati, akhinya raden Gayong jatuh miskin, Raden Ganyong kemudian bertani. Setelah jatuh miskin Dewi Kenyowati tidak menghargai dan menjalankan kewajibannya terhadap Raden Ganyong sebagai suaminya. Raden Ganyong bermasud akan kembali ke istri pertama Dewi Pembayun, tetapi Dewi Kenyowati tidak mau ditinggalkan, akhirnya menikuti Raden Ganyong. Dalam perjalanan menuju ke tempat Pembayun mereka melewati jembatan bernama Wot sirotolmustaqim Tanpa disadari, istrinya jatuh ke sungai yang disebut Lendut Berdapa (lumpur panas). Selama dalam Lendut Berdapa Dewi Kenyowati mendapatkan siksaan, kemudian ditemui malaikat Banakirun untuk diberi nasehat agar memenuhi kewajibannya sebagai seorang istri. Raden Ganyong berusaha menolong istrinya, tetapi ia mendapat bisikan gaib untuk bisa menolong Dewi Kenyowati, apabila dapat menemukan dua sendang. Akhirnya dua titik sendang dapat diketemukan yaitu Sendang Wanoroseta, dan di titik sendang Alam Barut, disini Dewi Kenyowati ditemukan. Mereka kemudian hidup bahagia di Gunung Srandil dan memiliki anak bernama Dewi Kenyami yang nanti menjadi raja pertama di Gunung Srandil (wawancara Tuhari, 20 Oktober 2018).

Ulasan tentang cerita tersebut mempunyai aspek antropologis yang dapat diteliti dengan pendekatan etnokoreologi. Cerita ini sebagai peristiwa perwujudan ekspresi budaya atau dalam konteks lingkungan budayanya, dengan cerita yang mengangkat kearifan lokal yang ada di daerah Bulu. Cerita itu mengangkat tema Islami atau cerita Islami seperti terdapat istilah Alun Alun Sirrollah dan Wot Sirotolmustaqim. Tetapi Setting kerajaan Majapahit mengilhami kepercayaan Hindu sehingga terjadi sinkritisme, yaitu paham aliran baru atau perpaduan beberapa aliran untuk mencari keseimbangan dan keserasian. Hal ini kemungkinan masyarakat Bulu sebelum menganut agama Islam dan Kristiani menganut agama Hindu. Tema cerita kesenian Srandul ini merupakan kearifan lokal yang mengilhami masyarakat untuk mengekspresikan dalam kesenian yang komunal. Kesenian Srandul yang hidup di Bulu Karangmojo memiliki fungsi sosial. Hal ini dibuktikan dengan adanya pengikat rasa solidaritas dan kegotong-royongan yang terbentuk karena kepercayaan mitos yang terdapat di dusun Bulu. Adapun urutan penyajian dari kesenian Srandul yaitu:

a. Awal pertunjukan, yaitu dengan permainan musik dengan tujuan mengumpulkan penonton.

b. Doa meminta perlindungan dan berkah 
kepada Tuhan Yang Maha Esa, yang

dipimpin oleh sesepuh kesenian Srandul

c. Adegan penurunan Bidadari

terdiri lima tarian yaitu

-Tari Mbabati ini menceritakan minta izin

kepada para leluhur

- Tari Boyongan menceritakan turunnya

bidadari ke bumi

- Tari Turunan menceritakan Bidadari untuk menjaga pertunjukan Srandul

- Tari Nyurupake menceritakan Bidadari manitis kepada penari

- Tari Ndatengake menceritakan penyambutan bidadari telah turun ke bumi.

\section{d. Adegan Sayembara}

e. Adegan Dagelan

f. Adegan Tari Sunthi, menceritakan

pertemuan Raden Ganyong dengan Dewi

Kenyowati

g. Adegan pelepasan Bidadari

\section{B. Sesaji}

Kesenian Srandul tidak akan terlepas dari budaya mistis, yaitu masih percaya dengan animisme. Teori Animisme suatu teori yang beranggapan bahwa asal mula dan dasar dari religi manusia adalah kepercayaan adanya makhluk-makhluk halus dan roh-roh yang menempati seluruh alam (Koentjaraningrat, 1958: 150). Untuk mewujudkan kepercayaan animisme tersebut mereka menggunakan sesaji. Sesaji harus dipersiapkan terlebih dahulu sebelum kesenian Srandul dimulai. Sesaji ini merupakan bagian dari pertunjukan Srandul. Tanpa sesaji kepercayaan masyarakat Bulu kesenian Srandul tidak dapat dipentaskan. Hal tersebut sesaji dimaksudkan agar memperoleh keselamatan dan hal terpenting ialah menurunkan bidadari agar menitis ke semua penari. Penempatan sesaji ada tiga tempat yaitu di sendang Ki Mojo, tempat rias para penari,daan tempat gamelan. Sesaji itu terdiri dari (1) Tumpeng dari beras merah dan putih, (2) Pisang Raja, (3) Ayam Ingkung, (4) Jenang Bening terbuat dari tepung pati dan gula pasir direbus, (5) Jenang Blohok terbuat dari beras diberi daun suji dan warna hijau, (6) Jenang merah dan putih terbuat dari beras yang merah diberi gula merah, (7) Jenang Solak Sundul terbuat dari tepung beras dib-keci luat bulat kecil dikasih gula merah, (8) Mega mendung, makanan terbuat dari agar-agar, (9) Klepon dan srabi dan jajanan pasar, (10) Minuman air putih, ko[i dan teh, (11) Bunga kanthil, kenanga , mlathi, dan mawar, (12) Dupa, (13) Serta beberapa hasil bumi, seperti kacang panjang, ketela, Sawi, kol dan lainlain.

\section{Dialog}

Kesenian Srandul merupakan bentuk dramatari ataupun teater daerah, yang didalamnya ada tari, dialog, dan tembang. Dialog dan tembang selalu menyertai pertunjukan Srandul. Seperti pada pertunjukan Kethoprak dan wayang orang, pertunjukan Srandul selalu membawakan 
suatu lakon. Serangkaian dialog dan tembang dalam kesenian Srandul sebenarnya melukiskan berbagai aspek kehidupan manusia. Dalam dialog dan tembang diutarakan tentang tata cara pergaulan sosial dan budi pekerti. Hal yang ingin disampaikan dalam pertunjukan Srandul adalah pergaulan sosial yang tercipta suatu suasana tenteram, damai dalam kehidupan.

Di samping mengetengahkan tentang pergaulan sosial, budi pekerti yang baik, juga disinggung tentang percintaan, pertengkaran, kemarahan dan lain lainnya. Petuah yang disampaikan bahwa kesombongan, kedengkian, kemarahan, harus dikendalikan agar tidak membuat orang lain sakit hati. Selain itu juga mengetengahkan mengenai perlunya diadaptasi kultural di kalangan generasi muda, terhadap generasi tua. Bagaimana anjuran orang tua mau mengerti terhadap keadaan sekarang, terhadap tingkah laku anak muda jaman sekarang, dan juga anak muda mengerti tentang budaya sopan santun. Selain dialog dan tembang itu berhubungan dengan kehidupan antar sesama manusia tetapi juga menyinggung tentang hubungan manusia denga Tuhan. Hal ini pada hakekatnya dialog dan tembang dalam pertunjukan Srandul menganjurkan agar manusia mencari keseimbangan antar kehidupan dunia dan akhirat.

\section{Gerak}

Salah satu ciri yang ada pada kesenian Srandul adalah perbendaharaan gerak yang sederhana. Gerak tari Srandul belum mempunyai standar yang baku, masih banyak gerak- gerak improvisasi yang dilakukan oleh para penari. Sifat gerak kesenian Srandul sederhana menurut kemampuan pemain dalam mengekspresikan karakter atau peran yang dibawakan. Gerak yang digunakan dalam pementasan antara pementasan yang satu dengan pementasan yang lain kadang-kadang ada perbedaan. Motif gerak tari Srandul merupakan gerakgerak sederhana yang mengacu pada gerak keseharian yang telah mengalami distorsi dan stilisasi. Gerak-gerak itu sebenarnya juga mengacu pada gerak tari gaya Surakarta dan Yogyakarta. Hal ini terlihat pada siakp jari-jari tangan yang ada sikap ngruji atau ngrayung, ngithing atau ngekithing, dan ngepel, malangkerik, ulap- ulap dan lainnya. Beberapa sekaran atau vokabuler gerak juga ada sembahan, srisigan, lembehan, lumaksana yang mencontoh gerak tradisi Surakarta dan Yogyakarta. Namun demikian karena para penari itu tidak mengalami pendidikan atau pembelajaran tari maka pelaksanaannya teknik geraknya tidak benar atau kurang bagus. Mereka belajar hanya menirukan yang mereka lihat. Beberapa vokabuler gerak tari Srandul yaitu; Sembahan, Lumaksono, Srisigan, Kuda-kuda kanan, Malang kadhak, Malang Kadhak miwir sampur, Lenggang kanan kiri dan Ulap-ulap kiri.

\section{F. Musik}


Dalam pementasan kesenian Srandul di dusun Bulu, Karangmojo, Gunungkidul ini ditampilkan tari-tarian dengan seperangkat alat musik yang sederhana. Beberapa instrumen alat musik tersebut antara lain Kendang, Jedor, Angklung, kecer, sejenis terbang dan gong Bonjor atau bambu. Dilihat dari instrumen musiknya tanpak adanya campuran pengaruh budaya Hindu dan Islam. Jedor dan terbang atau genjreng merupakan jenis intrumen seni budaya Islam yang sering digunakan dalam Slawatan dan Samroh. Sedangkan kendang dan kecer (ecrek-ecrek) merupakan jenis instrumen musik yang sudah lama sejak masa Hindu. Iringan pada kesenian Srandul merupakan satu kesatuan yang tak dapat dipisahkan. Iringan atau musik memperkuat suasana dan membantu penari untuk melakukan gerak serta merupakan patokan bagi para penari untuk memulai dan menyelesaikan gerak. Setiap adegan atau setiap pergantian adegan selalu ada lagu yang dinyanyikan oleh penyanggak sebagai pengatur laku. Ada dua alat intrumen yang sangat penting yaitu Kendang dan Jedor, Kedua alat musik ini ternyata tidak sematamata alat musik biasa, kedua alat musik ini dianggap sebagai benda keramat, karena sebagai rumah roh-roh penunggu kesenian Srandul. setiap malam Jumat Kliwon Alat musik tersebut juga diberi sesaji berupa bunga kenanga, mawar dan kantil serta membakar kemenyan. Ritual ini sekaligus berfungsi sebagai pemeliharaan hubungan antara anggota Srandul dengan roh-roh penjaga kesenian Srandul. Gending yang digunakan mengacu pada lagu dolanan, hal ini karena alat musik yang digunakan alat musik ritmik. Lagu-lagu tersebut seperti Cublak-cublak Suweng, Gundulgundul Pacul, Ilir-ilir, Kupu Kuwi, dan sebagainya.

\section{E. Tata Rias dan Busana}

Tata rias dan tata busana yang digunakan pada kesenian Srandul sangat sederhana. Para penari kesenian Srandul ini tidak mempunyai ketrampilan khusus dalam tata rias dan busana dalam seni pertunjukan. Pada awalnya para penari merias wajah hanya dengan bedak tabur sebagai dasar, kemudian untuk memerahkan pipi dengan sinwit merah, untuk membuat muka putih dengan sinwit putih, untuk membuat alis dengan pidhih dan langes. Perkembangan sekarang telah memakai alat make up kosmestik seperti, bedhak Viva atau Sari Ayu, Liptik, pensil alis, eye shedow, dan sebagainya. Untuk para penari gagah rias wajahnya agak tebal, dengan mempertebal atau mempertegas bentuk alis, kumis maupun brewok, untuk karakter alus hanya pempertebal alis dan garis wajah, untuk semua tokoh putri risa cantik. Busana yang dipakai pada penari Srandul juga masih sangat sederhana sesuai dengan fungsi busana untuk membantu dan memperjelas karakter yang ditampilkan. Menurut para penari Srandul busana yang sekarang ini telah 
mengalami perubahan dan perkembangan agra kelihatan menarik. Dengan adanya perubahan busana ini akan meningkatkan daya tarik para penonton. Dalam hal pakaian yang dikenakan para penari Srandul tampak berbeda-beda. Ada yang memakai Surjan dengan hiasan kepala destar yang diberi hiasan bulu-bulu, dengan kain wiron. Ada yang memakai kain cancutan sabuk lontong dan kamus timang, dan sampur, dengan celana panji-panji sebatas lutus yang diplisir benang emas, dengan kalung kace dan hiasan kepala songkok berjamang. Selain itu ada yang memakai celana panji-panji, denagan kain sapit urang sabuk lontong, kamus timang dan sampur, hiasan leher kalung kace dan hiasan kepala seperti tropong pada wayang orang. Untuk yang tokoh alusan dengan memakai celana panji, kain wiron jebolan sabuk lontong, kamus timang dan sampur dengan baju rompi hiasan leher kalung kace, hiasan kepala jaman.

\section{F. Waktu dan Tempat Pertunjukan}

Kesenian Srandul biasa dipertunjukkan di tanah lapang atau di halaman rumah yang dibuatkan panggung. Tempat tersebut dibuat arena segi empat yang dipagari bambu, di tengah-tengah diberi tajub yang diberi lilin yang berfungsi sebagai pusat pementasan. Penari Srandul menari mengelilingi tajub. Untuk tempat pementasa Srandul dalam Upacara Bersih Desa ini bertempat di depan sendang Kyai Mojo dusun Bulu. Tempat itu dipilih karena Sendang Kyai Mojo merupakan tempat yang di sakralkan. Selain itu sendang Kyai Mojo merupakan sumber air bagi masyarakat dusun Bulu yang dipercaya masyarakat dusun Bulu sebagai tempat bersemayamnya Kyai Mojo. Menurut Tuhari sesepuh dusun Bulu sejak nenek moyang mereka pementasan kesenian Srandul dalam Upacara Bersih Desa selalu bertempat di Sendang Kyai Mojo. Waktu pementasan Srandul bisa siang hari dan malam hari. Untuk Upacara Bersih Desa di dusun Bulu, Karangmojo ini pementasan dilakukan pada siang hari dari sekitar jam 10.00 sampai jam !6.00 sore. Untuk Tari pembukaan dari jam 10.00 sampai jan 11.30. kemudian istirahat untuk melaksanakan sholat Jumat dan kemudian mulai lagi jam 13.00 setelah selesai sholat Jumat sampai selesai kira-kira jam 16.00. Pelaksanaan Upacara Bersih Desa di dusun Bulu, Karangmojo, Kabupaten Gunungkidul ini selalu hari Jumat Kliwon. Kalau bulan Sapar itu pas tidak ada hari Jumat Kliwon maka dilakukan setelah hari Jumat Kliwaon bulan sebelumnya. Sesuai dengan pendapat Soedarsono dalam penyelenggaraan Upacara dengan pelaku terpilih, tempat terpilih, waktu terpilih, dan selalu ada sesaji.

\section{SIMPULAN}

Kesenian Srandul ini merupakan tarian yang diiringi dengan seperangkat gamelan yang amat sederhana. Srandul dapat 
dipentaskan di halaman terbuka yang dibuat pengiring. Kesenian Srandul ini masih panggung ataupun di pendapa rumah. sangat dibutuhkan oleh Pendukung kesenian srandul dusun Bulu ini masyarakat pendukungnya, hal ini terbukti kebanyakan para petani, dan para mudaselalu dipentaskan dalam Upacara Bersih mudi masyarakat dusun Bulu. Dari segi Desa di dusun Bulu Kecamatan perannya pemain Srandul dapat Karangmojo Kabupaten Gunungkidul digolongkan ke dalam dua kelompok, yaitu Yogyakarta. sebagai kelompok penari dan kelompok

\section{DAFTAR PUSTAKA}

Koentjaraningrat, 1983, Pengantar IImu Antropologi, Yogyakarta: Gajah Mada University Press.

Pigeaud, 1938, Javanse Volksvertoningen, Yogyakarta: Volkslectur Batavia.

Sumardjo, Jacob, 1987, Perkembangan Teater Modern dan Sastra Drama Indonesia, Bandung: PT. Citra Aditya Bakti.

Soedarsono, 1986, Indonesia Indah: Tari Tradisiona Indonesia, Jakarata: Yayasan Harapan Kita. , 1985, Peranan Seni Budaya dalam Kehidupan Manusia Kontinuitas dan Perubahan, Ygyakarta: Gajah Mada University Press. University Press. 1990, Seni Pertunjukan Indonesia di Era Globalisasi, Yogyakafrta: Gajah Mada

\section{Nara Sumber}

1. Kasino, 65 th, sesepuh dusun Bulu

2. Sudino, 55 th, kadus dusun Bulu.

3. Suparman, 45 th, pemusik kesenian Srandul

4. Tuhari, 68 th, sesepuh dusun Bulu

5. Wahyu, 50 th. Penari kesenian Srandul 